\title{
Changes in a benthic community associated with dense beds of a burrowing deposit feeder, Callianassa californiensis
}

\author{
Martin H. Posey \\ Oregon Institute of Marine Biology, Charleston, Oregon 97420, USA
}

\begin{abstract}
Various functional group hypotheses have provided different predictions for the influence of mobile deposit feeders on the composition of marine soft-sediment communities. Two that have received particular attention are the trophic group amensalism and mobility mode hypotheses. Trophic group amensalism suggests that deposit feeders will primarily affect suspension feeders through resuspension of sediments while a mobility mode approach suggests that sediment disruption is the mechanism of interaction, with sedentary organisms being the group most adversely affected. The macrofauna around a dense intertidal bed of the burrowing ghost shrimp Callianassa californiensis (Dana) was studied to test the predictions of these hypotheses. Most sedentary species, including deposit feeders, had much lower numbers within a dense shrimp bed compared to adjacent areas of low C. californiensis numbers. However, there was no change in faunal richness. These distributions are consistent with a mobility mode of interaction and are in contrast with recent studies of the ghost shrimp's effect on subtidal bivalve populations.
\end{abstract}

\section{INTRODUCTION}

Physical parameters have long been known to have a major influence on the distribution of organisms in soft sediments. Many studies have shown that large-scale patterns in species' abundances are often correlated with changes in sediment grain size and sorting (see Gray 1981, Peres 1982). Small-scale patterns can be the result of current velocity directly affecting larval settlement (Eckman 1983, Hannan 1984). During the past decade, however, it has become increasingly clear that local physical characteristics can also be strongly influenced by resident organisms. Several 'functional group' hypotheses propose that habitat modifications by a group of species may exclude certain organisms with different lifestyles. The trophic group amensalism hypothesis (Rhoads \& Young 1970) suggested that deposit feeders may inhibit suspension feeders by increasing the amount of resuspended material. The increased suspended matter would clog the filtering apparatus of suspension feeding species, limiting them primarily to coarser sands where deposit feeders are fewer. Woodin (1976) expanded the idea of functional groups by proposing that burrowing deposit feeders, tube builders, and suspension-feeding clams formed distinct assemblages, each creating conditions unfavorable to the survival of larvae of the other groups (adult-larval interactions). Burrowers may disrupt the sediment, preventing recruitment by larvae of tube builders or clams. Dense assemblages of suspension-feeding clams would filter most larvae from the overlying water while dense beds of tube builders would bind sediments or defecate over the tideflat surface. Relative mobilities of adult organisms have also been suggested as a primary criterion of interaction (Brenchley 1981, 1982). The more motile animals may disrupt the sediment, thereby preventing the establishment of sedentary forms, while sedentary organisms will tend to bind sediments, inhibiting burrowing. Although the mechanism of interaction differs, such functional group theories seek to explain the occurrence of distinct assemblages of species in soft sediments in terms of interactions between functionally different organisms.

The ghost shrimp Callianassa californiensis (Dana) is a burrowing deposit feeder, found on sandflats from Alaska to Baja California (MacGinitie 1934). Ghost shrimp live in burrows up to $0.5 \mathrm{~m}$ in depth and may form dense beds of over 500 ind $\mathrm{m}^{-2}$. Their activity results in continual reworking of near-surface sedi- 
ments, in a dense bed often fluidizing the sediment to an almost quicksand quality (MacGinitie 1934, Roberts et al. 1981, Bird 1982). However, the intensity of shrimp activity varies seasonally, being greatest during summer (Posey 1985). In Oregon and Washington estuaries, dense ghost shrimp beds are generally restricted to the high and mid intertidal (Hedgepeth 1952, Thompson \& Pritchard 1969, Swinbanks \& Murray 1981). The seaward limit of these shrimp beds may be quite abrupt with an order of magnitude decline in density over a horizontal distance of only 1 to $2 \mathrm{~m}$ and a vertical profile of only a few centimeters (pers. obs.).

Given the proposed importance of burrowing deposit feeders in soft sediments (Rhoads \& Young 1970, Woodin 1976, Brenchley 1981), one expects that dense beds of Callianassa californiensis will have a strong effect on the distribution or richness of benthic fauna. Several researchers have reported effects on the densities of certain animals (e.g. Ronan 1975, Brenchley 1978, Bird 1981, Murphy 1985). However, the predicted changes may vary depending on whether the ghost shrimp affects other organisms through trophic group amensalism or mechanisms involving sediment disruption (as proposed in the mobility mode and adult-larval interaction hypotheses). As part of a general study of the zonation of $C$. californiensis beds in Oregon, fauna were compared from areas of varying shrimp density to determine if there are correlations in abundance or species richness with the ghost shrimp. Because of seasonal variations in shrimp activity, community effects of $C$. californiensis were also expected to differ between seasons. These results are compared to the findings of other studies on Callianassa and the observed patterns are used to test the predictions of trophic group and mobility-mode functional group models.

\section{METHODS}

Faunal abundances were examined in and around a dense mid-intertidal Callianassa californiensis bed at Valino Island within the South Slough Estuarine Sanctuary, Coos Bay, Oregon (Fig. 1). The lower boundary of the bed marks an abrupt change in shrimp numbers with densities declining from 100 ind $\mathrm{m}^{-2}$ to 2 to 3 ind $\mathrm{m}^{-2}$ over a horizontal distance of less than $2 \mathrm{~m}$. Although the lower edge became somewhat less abrupt during winter, the position of the bed remained relatively constant during the $2 \mathrm{yr}$ of study. The substrate consisted primarily of fine sands $(0.125$ to 0.250 $\mathrm{mm}$ ) with slightly coarser sediments within the ghost shrimp bed.

The general approach employed in this study was to observe correlations between Callianassa californiensis density and the abundances of infauna. This

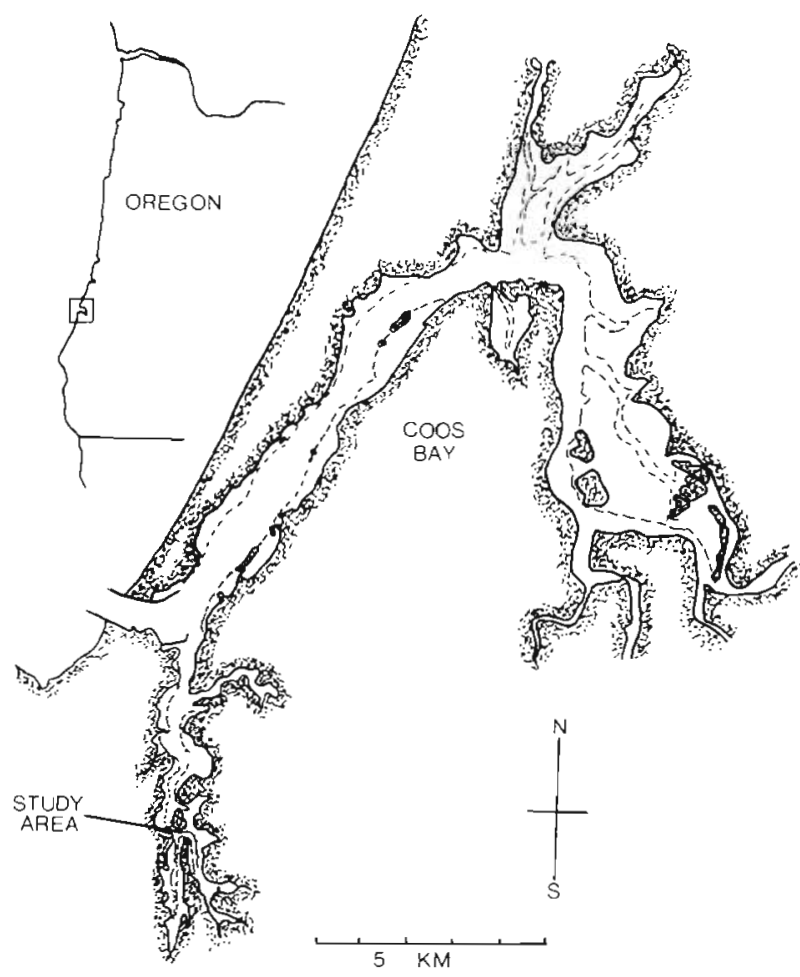

Fig. 1. Location of sampling

approach was used to avoid problems in interpretion of experimental artifacts, such as disturbance or succession in defaunated patches. The problem of determining the cause of observed patterns will be discussed later. Benthic cores were collected in 3 areas: (1) within the ghost shrimp bed; (2) along the transition zone from high to low $C$. californiensis density (intermediate density); and (3) in an area of low shrimp abundance $3 \mathrm{~m}$ from the ghost shrimp bed. The total distance between samples within and outside the shrimp bed was 5 to $6 \mathrm{~m}$ and all 3 areas were at virtually the same tidal height, approximately $1 \mathrm{~m}$ above mean lower low water (MLLW). Sampling location within each of these zones was chosen haphazardly with the toss of a shell. Three replicates were taken in each area at roughly bimonthly intervals from 1982 to January 1983 (March, June, July, September, October, January) and 5 samples were taken from each area at quarterly intervals from February 1983 to February 1984. The 1982 data were combined into seasonal categories for examination of seasonal variations in faunal responses to ghost shrimp bioturbation (Spring: March to May; Summer: June to August; Fall: September to November; Winter: December to February). These intervals roughly correspond to the rain and upwelling cycles prevalent along the Oregon coast; maximum rainfall occurring 
between December and February and strong upwelling being present in June and July.

Cores were $12.5 \mathrm{~cm}$ in diameter and $15 \mathrm{~cm}$ deep. They were immediately preserved in $4 \%$ formaldehyde with rose bengal dye added, sieved after 4 to $5 \mathrm{~d}$ on a $0.5 \mathrm{~mm}$ screen, and transferred to $70 \%$ ethanol for storage (Gonor \& Kemp 1978). The numbers of whole animals or heads were recorded.

A 2-way analysis of variance (ANOVA), blocking for differences between years, was used to test the effect of ghost shrimp density and interactions between shrimp density and season on species abundances. Blocking for years was considered necessary because of the unusual sea conditions associated with the $1983 \mathrm{El}$ Nino/Southern Oscillation event along the west coast of North America. $F_{\max }$ tests (Sokal \& Rohlf 1981) for the species examined indicated that variances were heterogeneous between sampling dates and a $\log _{10}(x+1)$ transformation was applied to achieve homogeneity. The absence of some species from a sampling location on certain dates (resulting in zero variances for that cell) was not considered to be a major problem since recalculation of the ANOVA substituting small artificial variances in these cases did not yield noticeably different results. All ANOVA's were calculated with the General Linear Models Procedure of the Statistical Analysis System (Ray 1982). Since a significant interaction effect may be expected if shrimp activity varies seasonally, it should be noted that in a Model I ANOVA, such as used here, the presence of significant interactions does not invalidate an examination of main effects (Sokal \& Rohlf 1981).

\section{RESULTS}

Forty-nine taxa were identified from the South Slough site, 37 to the generic or species level (see Posey 1985 for complete listing). Over $95 \%$ of the individuals were represented by only 9 taxa. A single species, the tanaid Leptochelia dubia, constituted 44 to $75 \%$ of the animals during each sampling period.
The relation between species richness and ghost shrimp abundance was examined by comparing the number of species in the 3 sampling areas with a G-test (Table 1), blocking for seasonal variations (Sokal \& Rohlf 1981). Differences were not significant, either when comparing all taxa $(\mathrm{G}=7.16 ; 16 \mathrm{df})$ or only those identified to the generic or species level $(\mathrm{G}=$ $4.82 ; 16 \mathrm{df})$. There was likewise no difference in the total number of taxa between areas of high and low shrimp density when the data were pooled over the 2 yr.

Even if high Callianassa californiensis density does not affect species richness, it may produce changes in the relative abundance of some residents. In particular, one might expect negative effects on suspension-feeding (Rhoads \& Young 1970) or sedentary organisms (Woodin 1976, Brenchley 1981). Because most species were uncommon, the effects of $C$. californiensis density on faunal abundance were examined only for the 9 most common taxa.

Three of these were spionid polychaetes: Pseudopolydora kempi japonica, Pygospio elegans, and Streblospio benedicti. All 3 are sedentary, tubedwelling deposit feeders (Fauchald \& Jumars 1979), although $P$. elegans and $P$. kempi japonica may be facultative suspension feeders under certain current regimes (Taghon et al. 1980). Both $P$. elegans and $S$. benedicti have often been considered as opportunistic colonizers (Boesch 1973, Grassle \& Grassle 1974, McCall 1977, Whitlatch 1981, Dauer 1984). Densities of all 3 spionid species were negatively correlated with that of Callianassa californiensis (Fig. 2). P. kempi japonica showed a seasonal variation in abundance and a slightly significant interaction between season and shrimp effects $(\mathrm{p}<.05)$.

Three tube-building crustaceans, the amphipods Corophium sp. and Grandidierella japonica and the tanaid Leptochelia dubia, were also commonly observed at Valino Island. Corophium sp. was identified as Corophium brevis; however, the small number of individuals and lack of females on certain dates prevented accurate identifications for some samples.

Table 1. Faunal richness in and around a dense Callianassa californiensis bed

\begin{tabular}{|c|c|c|c|c|c|c|c|c|c|}
\hline & $\begin{array}{c}\text { Spring } \\
1982\end{array}$ & $\begin{array}{c}\text { Summer } \\
1982\end{array}$ & $\begin{array}{l}\text { Fall } \\
1982\end{array}$ & $\begin{array}{c}\text { Winter } \\
1983\end{array}$ & $\begin{array}{c}\text { Spring } \\
1983\end{array}$ & $\begin{array}{c}\text { Summer } \\
1983\end{array}$ & $\begin{array}{l}\text { Fall } \\
1983\end{array}$ & $\begin{array}{c}\text { Winter } \\
1984\end{array}$ & $\begin{array}{l}2 \mathrm{yr} \\
\text { total }\end{array}$ \\
\hline Number of samples per area & 3 & $\begin{array}{c}6 \\
\text { ( } 5 \text { below bed) }\end{array}$ & 6 & 8 & 5 & 5 & 5 & 5 & $\begin{array}{c}43 \\
\text { (42 below bed) }\end{array}$ \\
\hline \multicolumn{10}{|l|}{ Number of taxa taken per area } \\
\hline Within bed & 20 & 25 & 23 & 19 & 15 & 13 & 18 & 18 & 39 \\
\hline Transition zone & 1.8 & 21 & 24 & 20 & 17 & 20 & 17 & 18 & 35 \\
\hline Below bed & 15 & 25 & 26 & 22 & 20 & 22 & 22 & 25 & 39 \\
\hline
\end{tabular}



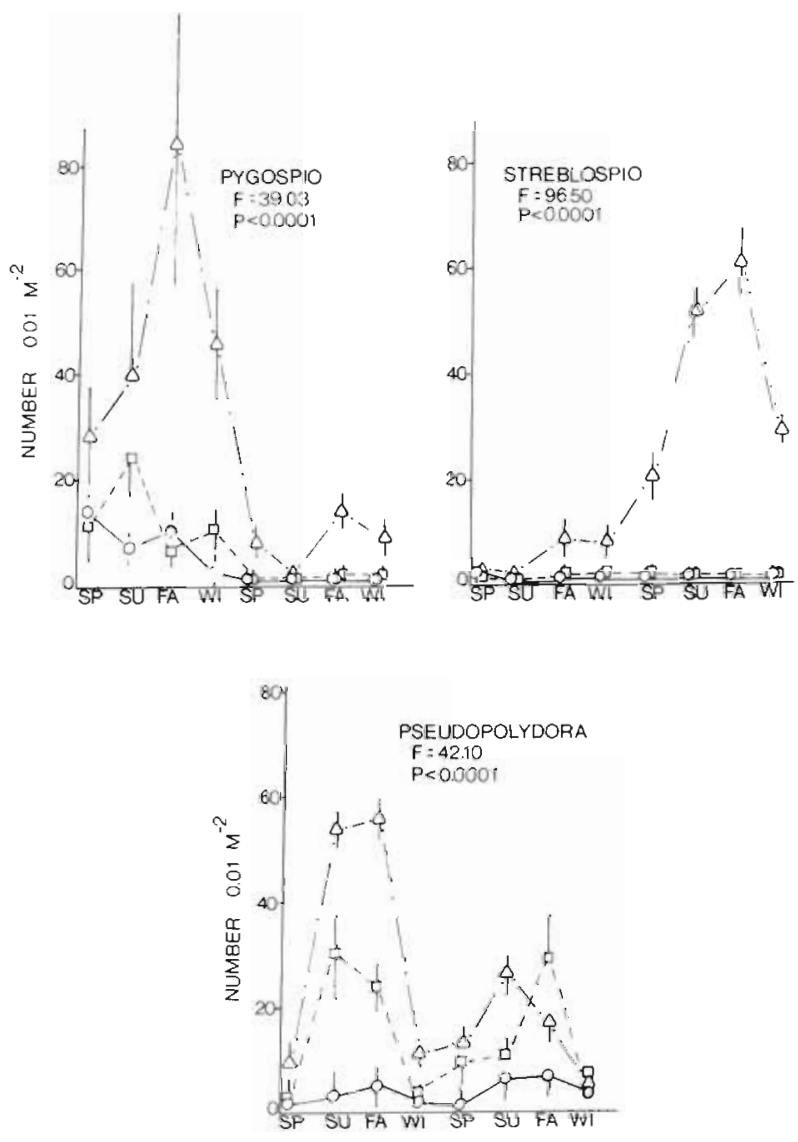

Fig. 2. Effect of a dense Callianassa californiensis bed on the abundance of spionid polychaetes. Number of replicates for each season is given in Table 1 and bars represent $\pm 1 \mathrm{SE}$. F values compare faunal abundances from the $3 \mathrm{C}$. californiensis densities. (O) within bed; (D) transition zone; $(\Delta)$ low $C$. californiensis density

Corophium does not easily fit into the usual trophic categories, since it uses filtering mouthparts to collect detritus from the tideflat surface (Miller 1984), and has been variously classified as a deposit feeder or suspension feeder (Brenchley 1978, 1981, Bird 1982). G. japonica and $L$. dubia deposit feed or scavenge (Smith \& Carlton 1975, Mendoza 1982).

Corophium sp. and Grandidierella japonica exhibited a spatial pattern similar to that of the spionid polychaetes, with lower abundances within the ghost shrimp bed and higher numbers in areas of low Callianassa californiensis density (Fig. 3). The numbers of both amphipods varied seasonally and strong seasonal variations in the effects of ghost shrimp density on abundance were observed for Corophium sp. $(\mathrm{F}=$ $6.56, \mathrm{p}<.0001)$. The interaction between season and shrimp density was only slightly significant for $G$. japonica.

In contrast to the amphipods, Leptochelia dubia abundance was not negatively correlated with ghost
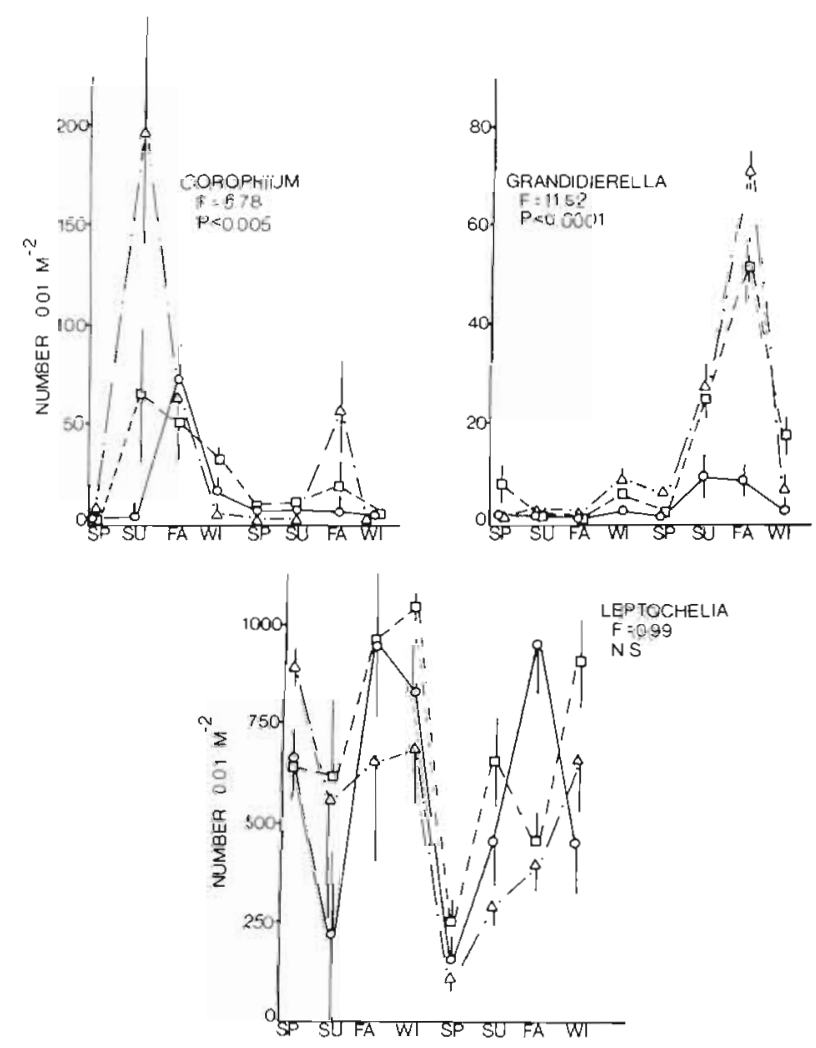

Fig. 3. Effect of a dense Callianassa californiensis bed on the abundance of tube-dwelling crustaceans. Number of replcates for each season is given in Table 1 and bars represent $\pm 1 \mathrm{SE}$. F values compare faunal abundances from the $3 \mathrm{C}$. californiensis densities. (O) within bed; $(\square)$ transition zone; $(\Delta)$ low C. californiensis density

shrimp density. Highest abundances occurred in the zone of transitional (intermediate) ghost shrimp density during 6 of the 8 seasons sampled.

The 3 remaining taxa, cumaceans, oligochaetes, and the amphipod Eobrolgus spinosus, are generally considered to be mobile forms (Smith \& Carlton 1975, Brenchley 1978, Barnes 1980). The dominant cumacean species were Cumella vulgaris and Hemileucon comes, of which at least $C$. vulgaris is a deposit feeder (Weiser 1956). The two are not treated separately because of problems in distinguishing them in early samples. However, they showed similar distributions with respect to shrimp density during the second year of sampling. Total cumacean abundance declined over the $2 \mathrm{yr}$, varying with both season and Callianassa californiensis density (Fig. 4). Highest numbers during summer, fall, and the first spring were observed in areas of low ghost shrimp density; but densities within the ghost shrimp bed and along the transition zone increased dramatically in winter, indicating seasonal variation in the effect of shrimp bioturbation $(F=8.18$, $\mathrm{p}<.0001$ ) 

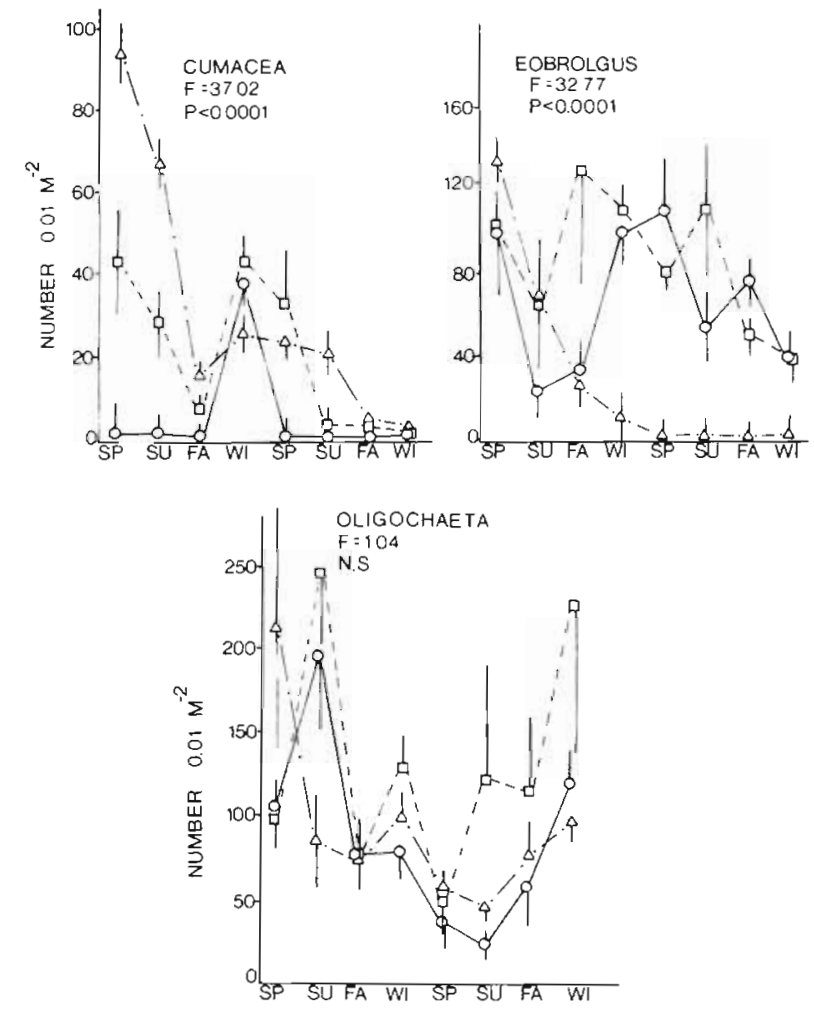

Fig. 4. Effect of a dense Callianassa californiensis bed on the abundance of mobile fauna. Number of replicates for each season is given in Table 1 and bars represent \pm 1 SE. F values compare faunal abundances from the $3 \mathrm{C}$. californiensis densities. (O) within bed; ( $\square$ ) transition zone; $(\Delta)$ low $C$. californiensis density

Eobrolgus spinosus (= Paraphoxus, see Barnard \& Barnard 1981) is an active burrower (Smith \& Carlton 1975, Brenchley 1981, Bird 1982), classified by Brenchley (1981) as a suspension feeder. E. spinosus abundance was initially high in areas of low Callianassa californiensis density but declined steadily throughout the 2 yr period (Fig. 4). During most sampling periods, highest abundances of this amphipod were found within the ghost shrimp bed or from the transition zone. Although numbers of E. spinosus varied seasonally, interactions between season and shrimp density were not significant.

Dr. R. O. Brinkhurst (Institute of Ocean Sciences, British Columbia, Canada) identified oligochaetes from several of the South Slough samples as Limnodriloides victoriensis Brinkhurst \& Baker (pers. comm.). It was not possible to determine if other species of oligochaetes were common in the study area. Macrofaunal marine oligochaetes are generally considered to be mobile deposit feeders (see Brenchley 1978). No significant pattern of distribution with respect to Callianassa californiensis density was observed for the oligachaetes (Fig. 4).
In summary, abundances of 7 of the 9 most common macrofauna were strongly correlated with Callianassa californiensis density. Six of these showed highest densities with low or intermediate shrimp numbers. They included 4 sedentary deposit-feeding species, 1 mobile deposit-feeding taxon, and a sedentary organism of unclassified feeding mode. One mobile, suspension-feeding species achieved highest densities within a ghost shrimp bed. The 2 most abundant taxa, oligochaetes and a tanaid, were not significantly affected by ghost shrimp activity. Interactive effects between ghost shrimp density and season were strong for only 2 species.

\section{DISCUSSION}

The presence of Callianassa californiensis in softsediment habitats appears to modify several aspects of the physical environment. Bird (1982) suggested that C. californiensis reduces sediment organic content and affects sediment grain-size and sorting. Increased sediment resuspension has been observed under laboratory conditions (Brenchley 1978, Murphy 1985). Similar effects have been reported for Caribbean species of Callianassa (Aller \& Dodge 1974, Suchanek 1983) and records of Callianassa bioturbation are common in geologic studies of near-shore sediments (Picket et al. 1971, Dewindt 1974, Moreno \& Curros 1979).

The physical changes are coupled with changes in the infaunal community. Brenchley (1978) and Bird (1982) noted a negative correlation between the abundance of several sedentary organisms and dense Callianassa californiensis beds. Species affected included spionid polychaetes, Corophium spp., and the tanaid Leptochelia dubia. Highsmith (1982) also provided evidence that $L$. dubia was susceptible to bioturbation. Furthermore, C. californiensis may exclude certain bivalve species as well as a tubedwelling phoronid (Stevens 1928, Ronan 1975, Peterson 1979, Murphy 1985). Certain Caribbean species of Callianassa negatively affect suspension-feeding organisms and Thalassia growth (Aller \& Dodge 1974, Suchanek 1983). Spionid polychaete distributions were negatively correlated with that of Callianassa ceramica in Australia (Dorsey \& Synnot 1980). Bird (1982) also observed significantly fewer species within a C. Californiensis bed compared to beds of the sedentary burrowing shrimp Upogebia puggettensis, but no data were provided from habitats in which neither species was common.

This study of Callianassa californiensis in South Slough differs from previous ones in observing community changes in the field within only a few meters. Yet even along the lower edge of the shrimp bed examined here, abundances of several species were 
strongly correlated with ghost shrimp density. The primary discrepancy with earlier studies was that species richness remained unchanged, contrary to what might have been expected from Bird's (1982) results. Such a difference may arise from the more widely spaced sampling areas used by Bird (samples were more than $100 \mathrm{~m}$ apart along an estuarine gradient) or his lack of comparisons with areas that do not have burrowing shrimp. The effect of a decrease in $C$. californiensis activity during winter is unclear. Assuming some migration of benthic fauna, one might expect less difference between areas of low and high ghost shrimp density with a decrease in the rate of bioturbation. Such a pattern occurred among the cumaceans and the amphipod Corophium sp. (although for Corophium sp. this coincided with a period of generally low numbers). However, for other species interactive effects were slight or nonsignificant in comparison to the main effects of shrimp density and season. One possible explanation for this result may be that the application of a transformation masked interactive effects. Since one effect of a transformation is to produce additivity in the data, nonadditive interactions may not be apparent after its application. However, examination of faunal abundances over time (Fig. 2, 3 \& 4) does not suggest interactions that were not detected by the statistical analysis. A second explanation for this lack of an interactive effect may result from assuming that adult migration occurs over several meters. Among spionid polychaetes, both Streblospio benedicti and Pygospio elegans have been reported to emigrate in response to certain types of stress (Levin 1982). If there is no such emigration under low stress conditions in the field, if it involves only short distances, or is limited in the winter months, little reduction in spionid zonation would occur. Also, winter and spring represented a time of low abundance for several species in all 3 areas, suggesting low settlement or survival at this time.

The results from the benthic samples presented here have been correlative, involving comparisons of samples taken in different areas. Manipulations of shrimp numbers are desirable to demonstrate causal relations between shrimp density and faunal abundances. In a northern Oregon study, containers of defaunated sediment were placed within a dense ghost shrimp bed (Bird 1982). After 6 mo, there was an almost 5 -fold increase in spionid and capitellid polychaete densities and Corophium sp. densities increased by 3 to 4 times that in the surrounding dense bed. After 24 to $36 \mathrm{mo}$, Callianassa californiensis had successfully invaded the exclosures and the abundances of polychaetes and amphipods declined to those of the surrounding area. These results and laboratory observations on the effect of ghost shrimp disturbance on selected organisms
(Brenchley 1978, Murphy 1985), suggest that the distribution patterns seen in the South Slough study are at least partially a result of $C$. californiensis activity.

The presence of both mobile and sedentary deposit feeders in the South Slough community allows a test of the predictions for functional models based on mobility mode and trophic groups. Five deposit-feeding organisms reached their highest numbers outside a Callianassa californiensis bed, whereas numbers of one suspension feeder were positively correlated with $C$. californiensis abundance. Two other deposit feeders showed no significant difference in distribution with respect to the shrimp bed. The trophic group amensalism hypothesis (Rhoads \& Young 1970) would not predict a negative effect of a deposit-feeding shrimp on other deposit feeders, but would predict a negative effect on suspension feeders. A mobility mode hypothesis predicts a negative effect by ghost shrimp on sedentary organisms and a neutral or positive effect on mobile animals. Five of the 6 sedentary organisms examined in this study were negatively correlated with C. californiensis density, as was one of the mobile taxa. One mobile species was positively associated with the shrimp bed, and one mobile and one sedentary form were not significantly affected. Most of these relations appear consistent with predictions of a mobility mode hypothesis; however, the exceptions emphasize the need for a better understanding of species' habits and of other possible interactions influencing community composition. Levin $(1981,1982)$ has shown that aggressive competition among spionid polychaetes (Pseudopolydora kempi and Streblospio benedicti) is important to the spatial distribution of these worms. Similar interactions may provide an explanation for the lack of an increase in Leptochelia dubia in areas with low C. californiensis density. This relatively small crustacean may be particularly susceptible to aggression from larger polychaetes or amphipods, both of which had higher densities away from the ghost shrimp bed. Levinton $(1972,1977)$ proposed that deposit-feeding bivalve communities may be regulated by exploitive competition for food. Although exploitive competition would not explain the rapid response of many species to $C$. Californiensis under laboratory conditions (Brenchley 1978), it may occur in specific cases, in this study possibly for cumaceans.

The distributions of most infauna examined here tend to support a mobility mode of interaction, however care should be taken in generalizing these conclusions beyond this habitat. Although several researchers have noted distinct assemblages of suspension and deposit feeders in intertidal regions (Bloom et al. 1972, Myers 1977, Whitlatch 1977), Rhoads \& Young (1970) suggested that trophic group amensalism may occur only in subtidal areas. Several studies of subtidal 
communities have noted distinct assemblages of these trophic groups (Sanders 1958, Sanders et al. 1962, Driscoll \& Brandon 1973) and a reduction in filtration rates has been observed with increased suspended matter for certain species (Nowell et al. 1981, Grant et al. 1982, Murphy 1985). Aller \& Dodge (1974) and Murphy (1985) have found evidence that Callianassa spp. can affect flora and fauna subtidally through resuspension of particles rather than strictly via sediment disruption. It is becoming increasingly apparent that, depending upon the physical environment or species involved, several modes of interactions among functional groups may be important.

Acknowledgements. Many people assisted in the field work and interpretation of data for this study, especially Paul Rudy, Jeff Goddard, Marshall Pregnall, and John Stadler. Howard Jones from the Hatfield Marine Science Center and Lynn Rudy from the Oregon Institute of Marine Biology kindly checked species identifications. Special thanks go to Peter Frank who provided advice throughout this research. This work was partially supported by Grants-In-Aid of Research from Sigma $\mathrm{Xi}$ and some equipment was provided by the South Slough National Estuarine Sanctuary. This study is part of the research submitted to fulfill the requirements of a Doctorate degree.

\section{LITERATURE CITED}

Aller, R. C., Dodge, R. E. (1974). Animal-sediment relations in a tropical lagoon, Discovery Bay, Jamaica. J. mar Res. 32: 209-232

Barnard, J. L., Barnard, C. M. (1981). The amphipod genera Eobrolgus and Eyakia (Crustacea: Phoxocephalidae) in the Pacific Ocean. Proc. Biol. Soc. Wash. 94: 295-313

Barnes, R. D. (1980). Invertebrate zoology. Saunders College, Philadelphia

Bird, E. W. (1982). Population dynamics of the Thalassinidean shrimps and their community effects through sediment modification. Ph. D. dissertation, Univ. of Maryland, College Park

Bloom, S. A., Simon, J. L., Hunter, V. D. (1972). Animal sediment relations and community analysis of a Florida estuary. Mar. Biol. 13: 43-56

Boesch, D. F. (1973). Classification and community structure of macrobenthos in the Hampton Roads area, Virginia. Mar. Biol. 21: 226-244

Brenchley, G. A. (1978). On the regulation of marine infaunal assemblages at the morphological level: a study of the interactions between sediment stabilizers, destabilizers, and their sedimentary environment. Ph. D. dissertation, The Johns Hopkins Univ., Baltimore

Brenchley, G. A. (1981). Disturbance and community structure: an experimental study of bioturbation in marine softbottom environments. J. mar. Res. 39: 767-790

Brenchley, G. A. (1982). Mechanisms of spatial competition in marine soft-bottom communities. J. exp. mar. Biol. Ecol. 60: $17-33$

Dauer, D. M. (1984). High resilience to disturbance of an estuarine polychaete community. Bull. mar. Sci. 34: $170-174$

Dewindt, J. T. (1974). Callianassid burrows as indicators of subsurface beach trend, Mississippi River delta plain. J. sedim. Petrol. 44: 1136-1139

Dorsey, J. H., Synnot, R. N. (1980). Marine soft-sediment benthic community offshore from the Black Rock sewage outfall, Connewaire, Victoria, Australia. Aust. J. mar Freshwat. Res. 31: 155-162

Driscoll, E. G., Brandon, D. E. (1973). Mollusc-sediment relationships in northwest Buzzards Bay, Mass. Malacologia 12: $13-46$

Eckman, K. (1983). Hydrodynamic processes affecting benthic recruitment. Limnol. Oceanogr. 28: 241-257

Fauchald, K., Jumars, P. A. (1979). The diet of worms: polychaete feeding guilds. Oceanogr. mar. Biol. A. Rev. 17: $193-284$

Gonor, J. J., Kemp, P. F. (1978). Procedures for quantitative ecological assessments in intertidal environments. U.S. Environmental Protection Agency, Corvallis, Oregon, EPA-600/3-78-087

Grant, W. D., Boyer, L. F., Sanford, L. P. (1982). The effects of bioturbation on the initiation of motion of intertidal sands. J. mar. Res. 40: 659-677

Grassle, J. F., Grassle, J. P. (1974). Opportunistic life histories and genetic systems in marine benthic polychaetes. J. mar. Res. 32; 253-284

Gray, J. S. (1981). The ecology of marine sediments. Cambridge University Press, Cambridge

Hannan, C. A. (1984). Initial settlement of marine invertebrate larvae: the role of passive sinking in a near-bottom turbulent flow environment. Ph. D. dissertation, Woods Hole Oceanographic Institution and Massachusetts Institute of Technology, Woods Hole, Massachusetts

Hedgepeth, J. W. (ed.) (1952). Between Pacific tides. Stanford University Press, Stanford, California

Highsmith, R. C. (1982). Induced settlement and metamorphosis of sand dollar (Dendraster excentricus) larvae in predator-free sites: adult sand dollar beds. Ecology 63: 329-337

Levin, L. A. (1981). Dispersion, feeding behavior and competition in two spionid polychaetes. J. mar. Res. 39: 99-117

Levin, L. A. (1982). Interference interactions among tubedwelling polychaetes in a dense infaunal assemblage. $J$. exp. mar Biol. Ecol. 65: 107-119

Levinton, J. S. (1972). Stability and trophic structure in deposit-feeding and suspension-feeding communities. Am. Nat. 106: 472-486

Levinton, J. S. (1977). Ecology of shallow water depositfeeding communities, Quisset Harbor, Massachusetts. In: Coull B. C. (ed.) Ecology of the marine benthos. University of South Carolina Press, Columbia, South Carolina

MacGinitie, G. E. (1934). The natural history of Callianassa californiensis Dana. Am. Midl. Nat. 15: 155-177

McCall, P. L. (1977). Community patterns and adaptive strategies of the infaunal benthos of Long Island Sound. J. mar. Res. 35: 221-226

Mendoza, J. A. (1982). Some aspects of the autecology of Leptochelia dubia (Kroyer, 1842) (Tanaidacea). Crustaceana 43: 225-240

Miller, D. C. (1984). Mechanical post-capture particle selection by suspension- and deposit-feeding Corophium. J. exp. mar. Biol. Ecol. 82: 59-76

Moreno, E. C., Curros, P. V (1979). The paleontology of the Cretaceous of Los Condemios, Guadalajara Province, Spain. Boln R. Soc. esp. Hist. nat. Secc. Geol. 77: 67-90

Murphy, R. C. (1985). Factors affecting the distribution of the introduced bivalve, Mercenaria mercenaria, in a California lagoon - the importance of bioturbation. $J$. mar. Res 43: $673-692$ 
Myers, A. C. (1977). Sediment processing in a marine subtidal sandy bottom community: II. Biological consequences. J. mar. Res. 35: 633-647

Nowell, A. R. M., Jumars, P. A., Eckman, J. E. (1981). Effects of biological activity on the entrainment of marine sediments. Mar. Biol. 6: 48-57

Peres, J. M. (1982). Major benthic assemblages. In: Kinne, O. (ed.) Marine ecology, Ocean management, Part 1. Vol. 5, John Wiley and Sons, Chichester, p. 373-522

Peterson, C. H. (1979). Predation, competitive exclusion and diversity in the soft-sediment benthic communities of estuaries and lagoons. In: Livingston, R. J. (ed.) Ecological processes in coastal and marine systems. Plenum Press, New York

Pickett, T. E., Kraft, J. C., Smith, K. (1971). Cretaceous burrows - Chesapeake and Delaware Canal, Delaware. Paleontology 45: 209-211

Posey, M. H. (1985). The effects upon the macrofaunal community of a dominant burrowing deposit feeder, Callianassa californiensis, and the role of predation in determining its intertidal distribution. $\mathrm{Ph}$. D. dissertation, Univ. of Oregon

Ray, A. A. (ed.) (1982). SAS user's guide, statistics, 1982 edn. SAS Institute, Cary, North Carolina

Rhoads, D. C., Young, D. K. (1970). The influences of depositfeeding organisms on sediment stability and community trophic structure. J. mar. Res. 28: 150-178

Roberts, H. H., Wiseman, W. J., Suchanek, T. H. (1981). Lagoon sediment transport: the significant effect of $\mathrm{Cal}$ lianassa bioturbation. Proc. of the 4th Intl. Coral Reef Symp. I: $459-465$

Ronan, T. E. (1975). Structural and paleo-ecological aspects of a modern marine soft-sediment community: an experimental field study. Ph. D. dissertation, Univ, of California Davis

Sanders, H. L. (1958), Benthic studies in Buzzards Bay. I. Animal-sediment relationships. Limnol. Oceanogr. 3: $254-258$
Sanders, H. L., Goudsmit, E. M., Mills, E. L., Hampson. G. E. (1962). A study of the intertidal fauna of Barnstable Harbor, Mass. Limnol. Oceanogr. 7: 63-79

Smith, R. I., Carlton, J. T. (ed.) (1975). Light's manual: intertidal invertebrates of the central California coast. Univ. of California Press, Berkeley

Sokal, R. R., Rohlf, E. F. (1981). Biometry. W. H. Freeman, San Francisco

Stevens, B. A. (1928). Callianassidae from the west coast of North America. Publs Puget Sound mar. Biol. Stn 6: 315-369

Suchanek, T. H. (1983). Control of seagrass communities and sediment distribution by Callianassa (Crustacea, Thalassinidae) bioturbation. J. mar. Res. 41: 281-298

Swinbanks, D. D., Murray, J. W. (1981). Biosedimentological zonation of Boundary Bay tidal flats, Fraser River delta, British Columbia. Sedimentology 28: 201-237

Taghon, G. L., Nowell, A. R. M., Jumars, P. A. (1980). Induction of suspension feeding in spionid polychaetes by high particle fluxes. Science 31: 562-564

Thompson, L. D., Pritchard, A. W. (1969). Osmoregulatory capacities of Callianassa and Upogebia (Crustacea: Thalassinidae). Biol. Bull. mar. biol. Lab., Woods Hole 136: $114-129$

Weiser, W. (1956). Factors influencing the choice of substratum in Cumella vilgaris Hart (Crustacea, Cumacea). Limnol. Oceanogr. 1: 274-285

Whitlatch, R. B. (1977). Seasonal changes in the community structure of the macrobenthos inhabiting the intertidal sand and mud flats of Barnstaple Harbor, Massachusetts. Biol. Bull. mar. biol. Lab., Woods Hole 152: 275-294

Whitlatch, R. B. (1981). Animal-sediment relationships in intertidal marine benthic habitats: some determinants of deposit-feeding species diversity. J. exp. mar. Biol. Ecol. 53: $31-45$

Woodin, S. A. (1976). Adult-larval interactions in dense infaunal assemblages: patterns of abundance. J. mar. Res. 34: $25-41$ 